\title{
Werner Bergengruen (d. 1964) in Conversation with the Middle Ages: Significant Contributions to Twentieth-Century Medievalism
}

\author{
Albrecht Classen ${ }^{1}$ \\ ${ }^{1}$ University of Arizona, USA \\ Correspondence: Albrecht Classen, 1512 E 1t $^{\text {st }}$ St., 301 LSB, German Studies, University of Arizona, Tucson, AZ \\ 85721, USA. E-mail: aclassen@arizona.edu.
}

Received: July 29, 2021; Accepted: September 24, 2021; Published: September 29, 2021

\begin{abstract}
Medievalism has experienced an enormous popularity in the last decades, if not century, but the specific contributions by the Baltic German author Werner Bergengruen have not yet received full attention. In light of a selection of his novellas, we can identify him as a meaningful respondent to medieval themes, ideas, concepts, and values which he dealt with rather creatively, employing them for his own ethical, religious, or spiritual musings. Studying Bergengruen's novellas makes it possible not only to familiarize ourselves once again with one of the most popular German authors from the mid-twentieth century who has unfairly lost in popular appeal maybe since ca. 1970. Through his novellas we also gain intriguing keys to open innovative perspectives toward a variety of literary and didactic texts from the Middle Ages, which are not simply imitated here, but emerge as critical catalysts or sources for Bergengruen's own reflections on timeless human issues.
\end{abstract}

Keywords: Werner Bergengruen, medievalism, Gottfried von Straßburg, Gesta Romanorum, St. Christopher, sleep magic, falcons, doppelgänger

\section{The Middle Ages in the Twenty-First Century}

Although we find ourselves already well in the twenty-first century, the fascination and almost obsession with the Middle Ages continue unabatedly, at least in public, popular culture. In an odd manner, the medieval world seems deeply ingrained in western collective consciousness, and the more we are marching toward the postmodern era with all of its digitization and robotization, the more people seem to desire some medieval fantasies to compensate for the coldness and boredom in their own lives. (Note 1) Little wonder that novelists such as J. R. R. Tolkien and J. K. Rowland have experienced an enormous global popularity, and that any movie based somehow on the Middle Ages can be almost guaranteed an incredible box-office success (see, for instance, Harty 1999; Aberth 2003; Woods 2014; The Middle Ages in Popular Culture 2015; Spencer-Hall 2018) - especially if the moviemaker operates with King Arthur, the sword Excalibur, and Camelot as the iconic symbols of this universal, postRomantic intrigue about a past age.

This goes so far that many times we can hear clear resonances of the medieval world in public statements, images, concepts, speeches, and publications. How many people flippantly refer to the silly notion of the 'flat earth,' probably in response to the Monty Python movies, but overall reflecting a general modern conviction that people in the Middle Ages believed that the earth was flat (Wolf 2004)? We tend to chuckle when someone refers to the 'chastity belt,' unassumingly perpetuating a late medieval male joke about husbands' inability to control their wives' chastity, and there is a very good chance to discover such a belt in any of the countless 'medieval' museums all over the world, which also come along with the horror-inducing torture instruments allegedly commonly applied by members of the 'medieval' Inquisition to force innocent victims to confess to all kinds of crimes (witch craze) (Classen 2007).

Most recently (March 15, 2021), US Sen. Sheldon Whitehouse (D-N.Y.) penned a letter addressed to newlyconfirmed U.S. Attorney General Merrick Garland asking him to open up the FBI investigation into the background check of now sitting Supreme Court Justice Brett Kavanaugh. In this letter, in which he claimed that the FBI had refused to carry out its full duties during the hearings at that time (2018), probably under pressure of former President Donald Trump, Whitehouse resorted to deeply medieval imagery to make his point: "“in this matter, the shutters were closed, the drawbridge drawn up, and there was no point of entry by which members of the public or Congress could provide information to the FBI." (Note 2) What would we do today, rhetorically and conceptually, at least with tongue in cheek, without the treasure trove of the Middle Ages? Consequently, both 
medievalists and modern literary scholars have energetically pursued research into Medievalism, which by now might even be considered an entire scholarly subfield all by itself (for a great research survey, see Müller 2010; for political medievalism, see Elliott 2021).

\section{Werner Bergengruen vis-à-vis the Middle Ages}

Curiously, however, one of the most influential modern German authors, who exerted a profound influence on whole generations of readers, Werner Bergengruen (1892-1964), is hardly ever mentioned in that context. Moreover, his works have generally mostly disappeared from public view, i.e., especially from bestseller lists, reading lists for students, book clubs, and other records; and while he used to be the veritable 'schoolbook' author of his time, he is hardly mentioned today, and only some people among the older generation which had graduated with the Abitur or Matura roughly until ca. 1970 or 1980 seem to remember him to some extent.

Granted, there might be good reasons to leave him aside today, as many modern scholars would argue, because he was a rather traditionalist author, conservative in his outlook, deeply religious - he had, together with his wife (Jewish through her maternal grandmother) converted to Catholicism in 1936, which extremely irritated the Nazis so much so that they excluded him from the Reichsschriftumskammer - and, worst for many among those who belonged to the student protest groups in 1968ff., he had successfully continued with his literary career throughout the entire Nazi regime despite various bans imposed on him. His "inneres Exil" became the anathema for modern audiences, although Bergengruen had powerfully spoken out many times against the Nazis both during their regime and after; he had published sharply formulated, though veiled criticism of Hitler, and had bitterly lamented about the suffering of the German people under his regime (see, for instance, his collection of poems, Dies irae, 1945). Worst of all for those critics, however, Bergengruen never addressed the Holocaust as such in explicit terms, did not engage with the suffering of Jews in Germany, or the postwar period (such as Heinrich Böll, Siegfried Lenz, or Wolfgang Borchert) and thus suddenly saw himself, quite unfairly, as a persona non grata within the Germanspeaking world of literature since the latter part of the twentieth century. (Note 3)

Although there is a Werner-Bergengruen Society trying to maintain his memory as a significant modern German author and poet, (Note 4) and although there have been some attempts in recent years to bring Bergengruen back to public awareness and to restore the previous respect which he had enjoyed as one of the major twentieth-century writers, he is probably virtually unknown among most Germanists, not to speak of Anglophone scholarship. (Note 5) Nevertheless, however we might want to evaluate Bergengruen's novels, novellas, essays, and poems, and however we might view his political stance both during the Nazi regime and after WWII, we can greatly profit from his writings in literary-historical terms if we examine how he responded to and utilized medieval German and European literature as inspiration for his own work. This paper, however, does not intend to pursue a socialpolitical interpretation, perhaps measuring Bergengruen up to contemporary standards of twenty-first-century literature. Instead, the focus will rest on the question how this author resorted to a variety of medieval sources as inspiration for his own work, adapting and transforming them for his own purposes.

As far as I can tell, scholars investigating medievalism have normally taken as their starting point some medieval literary works and then have shown how it was received, adapted, and transformed into some modern text, film, or art work. (Note 6) Here I want to proceed the opposite way and take a good look at Bergengruen first and then analyze how he drew from and was influenced by medieval literature for his own topics. The intention is not to identify any specific translation or imitation of a medieval work carried out by this Baltic-German author, but to determine the extent to which medieval and early modern literature inspired him in a variety of significant ways and how he translated medieval ideas into universal messages also for the modern audiences. (Note 7) Implicitly, I also want to refocus our attention as literary scholars to Bergengruen's works which certainly deserve our respect both for their inherent quality and for their uniqueness of his thematic selections. Even if some critics might reject him as a neo-Romantic, or neo-Realist in the vein of Theodor Fontane, for instance, there are countless cases in his œuvre that prove to be considerably innovative, intriguing, and valuable for their insights into the human condition throughout time.

While it is quite obvious that Bergengruen relied heavily on much historical material in many of his novels and novellas, we have not yet considered the specific connections and do not know some of the details concerning his medieval sources and how he adopted them for his purposes. Generally, we will discover that this writer made major contributions to medievalism without ever trying to appeal to popular culture which is often focused on the recovery of that time period through fantasy literature, festivals, movies, music, or paintings. His approach to the Middle Ages proves to be much more subtle, serious, thoughtful, sensitive, and selective, and we can safely assume that Bergengruen was not frivolously playing with medieval themes for quick effectiveness, as is often the case today when that time period is completely commercialized. 


\section{The Middle Ages in the Balticum - Bergengruen's Perceptions}

To begin with, I will examine what Bergengruen himself had to say about the Middle Ages, which was a culture and age still very close to his own original life in the Balticum, where he was born (in Riga) and grew up during his early years. In his autobiographical reflections "Bekenntnis zur Höhle" (probably from 1950; Dedication to the Cave), the author takes stock of his background and culture and thereby sheds important light on his approach to the Middle Ages (contained in Bergengruen, Die Feuerprobe, 1951, 49-55). More than anywhere else in northern Europe, the countries we call Estonia, Latvia, and Lithuania today were mostly spared from the effects of the French Revolution and maintained in many different respects their medieval structures and cultures, as Bergengruen at least perceived it. In Riga, as the author muses, "lebten wir mehr in einer mittelalterlichen oder barocken als in der modernen Welt" (51; we lived more in a medieval or Baroque than in a modern world). A radical change of a military and political kind affected that world after 1917 (end of WWI, the Russian revolution, the rise of the Weimar Republic), but the really dramatic, even traumatic experience happened only in the wake of the Hitler-Stalin Pact in 1939, just before the beginning of WWII. Referring to the entire Balticum, the narrator commented nostalgically: "ihre Geschichte endete damit, daß die achthundertjährigen Länder Livland, Estland und Kurland . . zusammen mit dem östlichen Polen den Preis ausmachten, um den 1939 die sowjetische Neutralität erkauft wurde. Die deutsche Bevölkerung wurde abtransportiert - ein Vorgang, den die behördliche Sprache als Umsiedlung bezeichnete" (51; their history ended with the eight-hundred years old countries Livonia, Estonia, and Kurland, together with eastern Poland, becoming the price with which the Soviet neutrality was bought in 1939).

Little wonder that Bergengruen grew up within a medieval framework, spiritually speaking, and that hence many of his major works were explicitly situated in the Middle Ages or the Renaissance, though certainly not as a kind of escapism from contemporary reality. A few examples may illustrate this phenomenon: In the collection of short legendary stories, Das Buch Rodenstein (1927; expanded in 1951, reprinted many times thereafter; The Castle Rodenstein; Bergengruen, Das Buch Rodenstein), numerous medieval or early modern tales, often deeply religious in nature, drawing from folklore, ghost stories, and religious legends, are redesigned for Bergengruen's own interests. The novel Herzog Karl der Kühne oder Gemüt und Schicksal (1930, revised in 1943; Duke Charles the Bold, or Attitude and Destiny) focuses on the life and death of the famous Burgundian Duke Charles the Bold (1433-1477), whose dreams of a new centralized empire between France and Germany rapidly came to an end when he fell in the battle of Nancy at the hands of the Swiss mercenaries. In his famous and highly popular novel, Der Großtyrann und das Gericht (1935; The Superior Tyrant and the Legal Court), the events take place in an Italian town during the Renaissance; most of the novellas contained in the collection Die Sultansrose (1946; The Sultan's Rose) are situated both in Spain and in Italy, as well as in Bavaria during the late Middle Ages and the early modern age. In Das große Alkahest (1926; The Great Alchemist), later retitled as Der Starost (1938), we encounter the world of Paracelsus and early modern alchemy. Der letzte Rittmeister (1952; The Last Cavalry Captain) and Die letzte Rittmeisterin: Ein Roman wenn man so will (1952; The Wife of the Last Cavalry Captain: A Novel, if You Will) are historical reminiscences, though not necessarily medieval in their foundation and draw, instead, from a variety of historical anecdotes. And Am Himmel wie auf Erden (1940; In Heaven as on Earth) takes us into the world of sixteenth-century Prussia when a pandemic strikes the country and challenges people in their social obligations, commitments, and duties.

Altogether, it would be useless to nail down Bergengruen as a medievalist, as a modern writer fixated on the Middle Ages or any other historical period, as historical as many of his narrative settings commonly prove to be. We would also misunderstand him if we were to characterize him as an opponent to the modern world, as an ideologue fighting democracy or the Enlightenment. Instead, we would do more justice to him if we recognized in him an author deeply fascinated by history in which he found countless examples of common human behavior which deserve to be retold in the modern time because they mirror so profoundly universal issues, conflicts, struggles, dilemmas, and quests.

People have always to make decisions, they are thus faced by quandaries and are challenged to balance out their ethical ideals with pragmatic, often material concerns of a selfish nature. In this regard, for Bergengruen, history was widely open as a field where he could draw extensive examples of human experiences from for his own writing. This in turn he explained with a reference to his own origin, the Balticum, which he viewed with considerable nostalgia:

Noch stand vieles in Kraft oder doch in Nachwirkung von den Lebensformen altgermanischer Autonomie; in Riga etwa behielt die mittelalterliche Ratsverfassung bis ins letzte Viertel des vorigen Jahrhunderts ihre Geltung. Der Einzelne galt viel, die Institution wenig; noch war die Persönlichkeit nicht von der Apparatur bedroht, geschweige denn verschlungen ("Bekenntnis 
zur Höhle," 52-53; Until then, much was still in full force or reflected much of the living conditions of the Old German autonomy; in Riga, for instance, the medieval city constitution was in place until the last quarter of the previous century. The individual counted much, the institution little; the personality was not threatened by the apparatus, and not at all engulfed by it).

As much as the author seems to idealize the past, as much does he praise individual freedom and the role of the individual personality in a rather modern fashion. Despite the praise of the Middle Ages, the poet actually uses that historical backdrop for his criticism of the modern bureaucratization and governmental control.

Most remarkably, in many of his novellas, Bergengruen engaged intensively with medieval literary motifs and concrete material, although he rarely, if ever, directly copied from Middle High German texts or adapted a specific romance or verse narrative as Thomas Mann did, for instance, when he wrote the short novel Der Erwählte (published in 1951), directly based on Hartmann von Aue's religious verse narrative, Gregorius (ca. 1200; see, for instance, Makoschey 1998, 123-235). We can hardly expect to encounter in Bergengruen's short prose narratives immediate paraphrases or imitations, which would have been contrary to his general approach. Nevertheless, in order to understand one of the author's major strategies in composing his text, we will have to realize that he regularly demonstrated a considerable degree of inspiration from the past, which then, however, was combined with his own creative abilities. In short, Bergengruen composed many of his texts influenced by many different medieval motifs and themes, and yet he then created his own versions, not willing to let the sources control his own concepts about individual freedom, human dignity, and ethical ideals.

In order to illustrate this phenomenon, I will examine only a handful of some of his most famous novellas in which we find specific references to medieval literature. By studying these novellas, which by and large exerted a tremendous influence on twentieth-century audiences both in German-speaking countries and abroad, we will gain a unique insight into the continued role and relevance of medieval themes in the modern era as pursued by Bergengruen. (Note 8) We can also expect that the study of Bergengruen's tales with their medieval topics and motifs will open new perspectives toward medieval literature and culture at large, so we will be able to build significant hermeneutic bridges between both periods. After all, as we have learned already, many of the major twentieth-century German and other authors demonstrated a keen interest in the Middle Ages and drew considerable inspiration from there, whether we think of Thomas Mann, Robert Musil, Bertolt Brecht, Hermann Hesse, Irmtraud Morgner, Adolf Muschg, or Gabrielle Alioth (Medievalism in Europe II 1996; Classen, "Hermann Hesse als Mediävist?," 1996; id., "Seinskonstitution im Leseakt," 1996; id., "Der Kampf um das Mittelalter im Werk Thomas Manns," 2003, 32-46). We can also include Bergengruen into this stellar list of modern-day German-language writers insofar as he creatively and innovatively employed medieval topics, themes, and motifs for his own purposes and thereby established himself as a historically-oriented writer who had much to say to his contemporary audience particularly because of the uniquely historical mirror in many of his tales which address, however, timeless issues.

\section{4. "Die drei Falken"}

One of Bergengruen's most popular novellas, "Die drei Falken" (1937; The Three Falcons) draws explicitly from medieval courtly culture, although the historical setting takes us somehow into the early Renaissance when the memory of those traditional values and ideals concerning the hunting with falcons and other birds of prey was fading already. (Note 9) The huge impact which this novella had can be recognized if we consider its many republications: 1937, 1940, 1945, 1947, 1951, 1956, 1957, 1958, 1959, 1963, 1964, 1965, 1966, 1969, 1972, 1978 , 1982, 1983, 1985, 1989, 2000, 2001; it was also translated into English in 1950 and 1966, into French in 1970, into Italian in 1962 and 1992, and into Polish in 1964 (data derived from WorldCat). The interest in this famous story by Bergengruen seems, however, to have faded since then with no further re-publications or translations after 2001, and it would be a valuable investigation to understand the reasons for this major shift in public interests.

"Die drei Falken" can serve our purposes particularly well because here, as is so often the case in Bergengruen's œuvre, he entirely turns away from topical, political, or current issues and focuses on a historical situation somewhere in the medieval kingdom of Naples in the fourteenth or fifteenth centuries. A famous master of the art of hunting with birds of prey, specifically with falcons, has died, leaving behind hardly anything of worth except for three most valuable birds. Although a fairly poor man, that master had been worshipped throughout the city and the entire region for his skills in domesticating those birds of prey and training them for this traditionally courtly art. A fraternity was even founded in the city to maintain this vanishing art, which had previously been, as we are also told, most famously practiced by the German Emperor Frederick II of Hohenstaufen (1194-1250). The latter, in fact, had been the author of the probably best manual of the art of falconry (see, for instance, Walz 1994), 
and in this novella we are told that the deceased master had owned a copy of an Italian translation. Rising to the occasion and reflecting on his own superior knowledge, he had used some of the empty pages in the back of the book to jot down some notes about his personal experiences (9).

The three falcons are to be auctioned off, and in that process major tensions surface between, on the one hand, the auctioneer, the notary public Albinelli, a passionate hunter with birds of prey, and an ignorant silk merchant, who had married the widow of the master's son and who is thus only a distant relative. Nevertheless, he tries with all of his might to get his hands on one of the falcons, that is, on the money to be paid for the bird. Albinelli is also driven by his personal desires, in a way rather selfishly because he is obsessed by the hope of acquiring one of the falcons for himself, which he admires for their noble character.

When the dead man's last will is being read out aloud, it is suddenly revealed that a homeless person, a limper, Cecco, had been the master's illegitimate son, who is now finally recognized and identified as one of the heirs. Almost like in many of the short stories and novels by Thomas Mann, Bergengruen here portrays the well-known tensions between capitalism and the arts, creating bitter tensions between the silk merchant and the entertainer/artist Cecco, while Albinelli pursues his own agenda. Ironically, however, while all are still debating how to handle the auction or the payout from the price for the falcons, the news arrives that one of the birds has escaped, which thus entangles the entire situation even further. Other heirs, such as the prior of a monastery and the city official in charge of the poor, demonstrate considerable generosity and nobility in this situation, whereas the silk merchant emerges as greedy, boisterous, and demanding, perhaps like the Lübeck merchant Köterjahn in Thomas Mann's novella Tristan (1903).

Surprisingly, the escaped falcon is later captured again, which changes the entire situation radically. But, closely following the concept of the genre of the novella, Cecco, while examining the bird, suddenly feels entirely disgusted by all the haggling and debating about the falcon and the price to be paid for it, so, pretending to operate without any skills, he loosens the noble bird's shackles and allows it to fly away once again because, as the novella insinuates, he considers freedom for such a noble bird more important than all the money which could be offered for it.

Albinelli, who had ardently waited for the moment to outbid all the others and to acquire this highly valuable falcon, is utterly distraught and almost collapses emotionally. Then, however, he suddenly remembers the ideals and values pursued by the deceased falcon master and realizes that Cecco had understood the nature of those birds of prey much better than they altogether. In a surprising move, he takes off his necklace which serves as a symbol of his membership to the fraternity and puts it on Cecco, admitting that the limper probably understood much more about the true nature of those noble creatures than everyone else in the fraternity and the city. Although he has to fend with an enormous emotional loss, no longer being able to 'possess' such a wild and free bird, he has recognized what represents the inner, noble spirit and value of falcons, whom he has to acknowledge as free spirits which ought not to be kept in captivity. Cecco's selfless action thus proved to be an expression of freedom which every noble being would desire.

While most scholars working with the 'falcon motif' have directly referred to Boccaccio's famous ninth story told on the fifth day in his Decameron (ca. 1350) about Federigo degli Alberighi and his most valuable falcon, it would be rather problematic to correlate Bergengruen's novella with that by his Italian predecessor more closely, although the definition of the novella as a genre has been commonly predicated on Boccaccio's story since the time of Paul Heyse's famous definition (Heyse and Kurz, ed., 1871, XIX-XX). Granted, in both texts we are explicitly alerted to the noble character of falcons, but Federigo actually kills his bird despite his great love for it because it is his last valuable property so he can serve his lady, who has suddenly come for a visit, a meal, not knowing that her only true wish is to ask for that falcon as a gift for her sick son. In Bergengruen's novella, by contrast, Cecco frees the falcon and allows it to escape, returning to nature and hence freedom. Nevertheless, we should pay attention primarily to the values and ideals represented by the falcon.

In Gottfried von Straßburg's Tristan (ca. 1210), falcons also play a significant role when the young protagonist visits the ship by Norwegian merchants who offer all kinds of birds of prey for sale, which fascinate Tristan and his foster-brothers. Nobility of character is consistently identified with falcons, and so is the concept of courtly love, as perhaps best expressed by Der Kürenberger in his falcon songs contained in Des Minnesangs Frühling (ca. 1170/1180). In Wolfram von Eschenbach's Parzival (ca. 1205) we also hear of a falcon, a young bird which has escaped from its owner and has tried in vain to capture a goose in the early morning. But the goose was wounded, and three drops of blood dropped onto the snow which had mysteriously fallen during that night. When Parzival arrives and observes those three drops of blood, he remembers his beloved wife Condwiramurs and falls into a trance thinking about her. Two of King Arthur's knights, the steward Kaye and young Segramors, rush out 
of the camp to fight against Parzival, but they are knocked down. Only when Gawain arrives, who immediately realizes Parzival's thoughts of love, can he bring the stranger back to reality by covering the drops of blood with a blanket. There is not much more said about the falcon, but we can be certain that Wolfram intended it to serve in symbolic terms, representing the nobility of character, love, and culture. Finally, and most ominously, Kriemhild's dream of a falcon in the Nibelungenlied (ca. 1200) indicates how much the falcon could represent, love, death, ideals, and values (Ermes-Körber; Miedema; Smets).

At closer analysis, however, it is not possible to correlate Bergengruen's novella more directly with any of those medieval sources, and yet his narrative is certainly predicated on the medieval ideal of courtliness, nobility, and freedom. We would have to consider more in detail what Emperor Frederick II had formulated about falcons at large and their character to understand Bergengruen's intention with this symbol, but the novella does not suggest that it was based at length or in detail on this famous medieval source.

In essence, the falcon, like all other birds of prey, needs to be tamed and trained before it can be used in hunting. This implies that the falcon has to repress its own wild nature and accept civilization, hence human culture, submitting under its master. Neither Frederick nor Gottfried, for instance, considered the desire for freedom as quintessential in their discussion of falcons. Bergengruen, on the other hand, highlighted the falcon's intrinsic desire for freedom as its greatest attribute. According to the medieval sources, which Bergengruen might or might not have consulted at greater length - particularly Boccaccio's story seems rather far removed from the modern narrative - the falcon had to become disciplined and to accept its master. The modern author, certainly somehow familiar with Frederick's text, which is even explicitly mentioned in the novella, transformed the motif into one concerning individual freedom and inner nobility, honor, and dignity. Almost more than his medieval predecessors, Bergengruen embraced the ideal of the nobility of the soul and character and glorified Cecco's action, allowing the freedom-loving bird to fly away. Curiously, but characteristically for this writer, the medieval background is virtually tangible, and yet the novella moves productively into a new direction, now thematizing the ideal of individual freedom, that is, freedom from capitalistic thinking, from social constraints, and material conditions. However, Bergengruen does not seem to have aimed for any kind of a political reading in this novella.

\section{5. "Die Feuerprobe"}

In his novella "Die Feuerprobe" (Bergengruen, Die Feuerprobe 1951, 1998; The Ordeal of the Fire), Bergengruen relied almost explicitly on Gottfried's Tristan (ca. 1210; Gottfried) because he appears to have predicated the entire story on the famous scene with the ordeal which Isolde has to undergo in the second part of the medieval romance (Bartlett 1986; Neumann 2010; Ziegler 2004; Dinzelbacher 2020). In both texts, the young woman is charged with adultery, though the evidence is not quite there in either case. The modern novella is located in Riga and takes place during the late fourteenth century, as we can tell because of a reference to a war involving the Victual Brothers (corsairs, or pirates), the Hanseatic League, and Riga. Those Brothers were roundly defeated and basically eliminated in 1398 in the battle of Gotland to which the narrator here does not yet refer (Dummschat 2016; Rohmann 2017).

Gripen Tidemann's wife Barbara is rumored to have had an affair with Schwenkhusen, but she appears to deny it adamantly without saying so explicitly. While her husband insists on her to undergo the ordeal of the fire, i.e., to hold a red-hot iron on her palm without being hurt as a test of her innocence, Schwenkhusen is said to have died in the sortie against the pirate troops. Almost miraculously, however, he had survived and returns to Riga. In virtual parallel, Barbara had agreed to submit under the ordeal, and to the great astonishment of everyone present, the iron does not burn her, as it normally would. Everyone hence regards her almost like a saint, and Tidemann feels greatest guilt in having accused his wife of being an adulteress. However, Schwenkhusen and Barbara then develop, apparently for a second time, a love relationship, and since she regards herself as being above all human laws having been graced by God during the ordeal, the two care now little about people's opinion. Yet, the novella comes to a shocking conclusion when on the second anniversary of the ordeal Barbara voluntarily asks for the iron, but this time, although it is not heated up, she burns herself badly, so both she and Schwenkhusen are exposed as adulterers after all.

In the case of Gottfried's Tristan, Isolde and Tristan are also guilty of being in love with each other although she is married to King Mark of Cornwall. We can leave aside the issue of the infamous love potion and concentrate on their affair which the poet projects as a case of a true, deep, almost sacred love relationship. At one point, the suspicion against the two grows so much in intensity that Isolde has to submit under the ordeal as well. Tragically, Isolde is all alone, not even having Tristan around to support her. But she orchestrates an amazing, almost operatic strategy, putting herself entirely in charge of the process. She instructs Tristan to appear in the guise of a pilgrim on the beach where the Cornish ship with all of them on board traveling to the site of the ordeal will arrive. Since 
the ordeal is so much associated with a religious ceremony, she refuses any man to carry her from the ship to the shore, except the pilgrim, who follows the order, but when he arrives back at the beach, he stumbles in such a way that they both fall down, with her landing in his arms, and this according to her secret command. This later allows her to swear the oath that she had never laid in the arms of any man except those of her husband, Mark, and, of course, the poor pilgrim.

Technically speaking, she thus does not utter a lie, so she is amazingly graced by God because she does not burn herself at all. The narrator goes so far as to call Christ a wind-swept sleeve, meaning that $\mathrm{He}$ can be manipulated by people according to their own wishes. Of course, Gottfried did not mean to be blasphemous; instead, he intended to ridicule the entire institution of the ordeal, which was then actually condemned by the Church during its Fourth Lateran Council in 1215, although the practice was continued in many parts of Europe far in the late Middle Ages (Neumann 2010).

Significantly, however, Bergengruen turned the satirical concept as developed by Gottfried upside down. Isolde survives the ordeal and can thereby ridicule the concept of this type of trial because it does not serve at all to evince her guilt or innocence. The modern German author also deals with the same situation, adultery, and he also allows Barbara to get off scot-free, but at the end she becomes a victim of her own hypocrisy and blasphemy. The only possible explanation for her survival of the first ordeal consists of her serious attempt to do penance and to appeal to God's help, her being filled with rue and regret. But when she picks up the cold iron two years later, she is no longer guilt-free, has resumed her adultery with Schwenkhusen, and is thus finally punished by God and stands to be harshly condemned by society for her lying, deceiving, and ultimately her blasphemy. Gottfried had ironically engaged with the human belief that people can request from God to intervene in earthly affairs, whereas Bergengruen reconfirmed this very belief and profiled Barbara as a person who presumptively regards herself as in supreme command of her own existence, yet at the end has to realize that her religious arrogance leads to her punishment by God after all.

The author did not situate the world of Riga society in any particular way within the late Middle Ages, and he certainly did not intend to idealize the past feudal structures. Even the practice of resorting to the ordeal is regarded generally as something highly unusual, out of the ordinary, and from the old days luckily being behind them. The narrative focus, however, rests on the inner struggles by the female protagonist and her constant temptations by her previous lover, Schwenkhusen. She falls for him a second time after he has returned from the war, although she wanted to reject him at first. Significantly, he seduces her most intensively when he follows her to a church service, but the real adultery then takes place when the two people meet in the forest outside of their estates where Barbara had withdrawn after she had triumphed in the ordeal.

If we were not confronted with the ordeal itself and if we did not know of the war against the Victual Brothers, the medieval framework of this novella would be almost impossible to detect. However, Bergengruen explicitly engages with the medieval theme of the ordeal and employs it intriguingly to illustrate the tensions between the married couple, between Barbara and the rest of the urban community, and the struggle involving her lover, Schwenkhusen. In essence, however, the novella does not really concern itself with a historical theme, but with questions regarding the individual's relationship with the divine, destiny, honor, and personal responsibility. From the conversations between Barbara and Schwenkhusen after his return from the war we can assume that they had had an affair after all despite her denial and despite the seeming proof of her innocence during the ordeal. However, since she had repented, confessed, and then apparently received God's absolution, the red-hot iron could not hurt her. Subsequently, both of them resumed their adulterous affair, and this made Barbara doubly guilty, meaning that even the cold iron could burn her badly.

Gottfried had basically approved the love relationship between Tristan and Isolde and projected it as a glorious situation, in which suffering and joy merged in one experience. The medieval notion of love was predicated on the dialectics of happiness and sorrow merged in one, as the poet's metaphor of the bitter bread in the prologue insinuates. At the end of the romance, the two lovers are expelled from the court and retire into the minnegrotte where they can enjoy a kind of utopian freedom (Tomasek 1985). Yet, once they have been rediscovered by Mark by chance, and are allowed to return to his court because Tristan has deceived the king with the help of the sword lying between him and Isolde once again, they happily accept this grace because life without honor, i.e., away from the social community, cannot be sustained for long.

Of course, at the end, they are both caught in flagrante by her husband, which forces Tristan to leave for good, while Isolde has to stay behind in sorrow. In Bergengruen's novella, by contrast, the lovers can get together again and enjoy their intimate company irrespective of society's watchful attention because divine intervention had granted Barbara the appearance/screen of a saint. However, she finally loses that screen and exposes herself to the 
public because she dares to challenge God Himself and pretends as if she could control even Him. In Gottfried's romance, the ordeal scene concludes with the audience invited to smile about the foolishness of the courtly world that believed in the 'truth' of the ordeal and yet was so utterly deceived by Isolde. We also notice the extent to which the medieval poet portrays Isolde as a master plotter who knows how to manipulate the entire court, including her own husband, while she directs her lover and has him carry out her instructions without fail. Altogether, Gottfried belittles the marriage between Isolde and Mark, whereas Bergengruen questions the quality of the marriage between Barbara and Gripen. But whereas for the medieval poet the love potion drunk by both lovers justifies, in a way, their profound affair, the modern poet seems rather reticent to reveal to his readers that an affair had actually taken place and that the rumor about Barbara was grounded in facts.

Yet, since Schwenkhusen and Gripen's wife begin with their affair once again, after she had been redeemed by God, she is ultimately severely punished, whereas her lover is extremely shamed and dishonored. In a fascinating and unique way, Bergengruen revaluates the ordeal as a valid instrument to learn about the divine function and to test the individual in face of destiny. Gottfried used heavy irony in his treatment of the ordeal, whereas Bergengruen resorts to this medieval theme to examine, once again, the individual's relationship with God. With tongue-in-cheek, we might even claim that Bergengruen was almost more 'medieval' than Gottfried himself, but certainly not in the vein of the Romantics; instead, he revived the medieval theme in order to probe, for his own time and age, the question of how much the protagonist can interact with the divine, live up to the social norms and ideals, and handle his/her own destiny.

\section{6. "Der nackte Kaiser"}

In addition, in "Der nackte Kaiser" (1946; The Naked Emperor) Bergengruen draws more directly from a wide ranging medieval narrative tradition and continues it for the sake of his own contemporary audience as if the historical distance between the early fourteenth century and the twentieth did not matter for him. And maybe, considering the content of his tale, it should not matter to us either because the story relates a timeless message of poignant relevance pertaining to the role of dictators, tyrants, or arrogant rulers at large (originally contained in Bergengruen, Die Sultansrose und andere Erzählungen, 1946). In essence, the emperor Jovinian is presented at first as an arrogant ruler who believes firmly that he has nothing to worry about here in this world and does not need to fear God. That biographical information, however, appears only late in the story, whereas it normally represents the first part of the medieval versions, such as in the Latin Gesta Romanorum, in the Spanish El Conde Lucanor by Don Juan Manuel, and in Herrand von Wildonie's "Der blôze keiser," to name the most important versions. It seems most likely that Bergengruen drew from the Gesta Romanorum above all (ca. 1270-1300), but the motif was highly popular throughout the entire Middle Ages and thus might have reached him through alternative channels (Classen, 2021).

The medieval poets emphasized consistently that the emperor was to be punished for his moral and ethical shortcomings, and once he had gone through a period of profound suffering and humiliation, he was granted his restitution as emperor because he had learned his lesson and then became an ideal ruler.

In Bergengruen's novella, the situation develops quite differently because the angel, who had taken on Jovinian's role as his doppelgänger, had pursued a surprising intention. There are no specific words about the emperor's wrongdoing, about his possibly dictatorial attitude, his arrogance, selfishness, or abuse of the people. Nevertheless, at the end the angel points out that certain things have gone wrong in the entire empire, whether corruption or crime, whether excessive luxury or violence against individuals or groups. God had to intervene and hence had selected the highest-ranking individual, the emperor, as the one who was noble enough to sustain the penance imposed by God. The margrave, realizing the truth of the matter, vehemently protests against this divine operation which ultimately had meant that they all had badly mistreated the emperor simply out of their own ignorance. None had been able to recognize the true emperor in his nakedness and misery, when another person who looked exactly like him was sitting in his throne. Indeed, the margrave is ashamed and afraid at the same time because the way of how he had treated the right person now deeply embarrasses him and makes him feel guilty.

The angel, however, explains the circumstances with a reference to global, collective guilt which had affected the entire empire. Only one person, the emperor, was regarded as strong enough to become a tool in God's hands, and his extensive penance, being ridiculed and abused by people everywhere, ultimately served the entire people as a form of regaining their redemption. As the angel thus indicates, a true leader would not only reap the profit from his high position for himself but would in reality serve the principle task of being the representative of collective conscience, hence also sinfulness. Insofar as Jovinian was the least guilty of them all, and yet the most nobleminded, he had been selected by God to carry out this hard and difficult penance. 
Bergengruen concludes his novella in a somewhat mysterious fashion, pointing out that the empress soon thereafter delivered a boy, who later did not ascend to his father's throne. Nevertheless, almost too esoterically for modern tastes and certainly puzzling for us today in a political context, he himself had heirs, and one among them continued with the tradition, serving as the Roman emperor. Whereas the medieval poets consistently used this narrative motif to develop a kind of 'mirror for princes,' warning the kings, current or future, about the danger for themselves serving in this position since it could easily lead to a form of dictatorship, Bergengruen moralizes this account and reads it from a religious-spiritual perspective. In his version of the medieval trope, the emperor has to undergo sequence of of his suffering because all people have become guilty and are in great need for redemption by their leader. Only the strongest and most noble among them, the emperor, is deemed worthy enough to undergo the penance, which ultimately creates sufficient repentance for all of them. Involuntarily, we might say, Justinian assumed almost a Christ-like function, and so did someone among his descendants, at least an individual belonging to future generations beyond his own son.

Whether Bergengruen envisioned an ideal leader for his own time, or whether he even dreamed about a global savior beyond all the political horrors of his own time (1946), does not need to be decided here. Ideologically or politically speaking, the writer might have pursued a dangerously naive position, particularly after those twelve years of the Nazi regime, or he might have formulated in his story a true message about how to improve all political structures by way of returning to medieval concepts of the ideal, ethically and spiritually motivated ruler. At any rate, "Der nackte Kaiser" presents an intriguingly productive and constructive narrative strategy predicated on a strong medieval tradition, looking toward the future of the political system following the horror regime by way of drawing from a very influential model more than seven hundred years ago. As is so often the case in Bergengruen's writings, the past and the present interlock with each other, which consistently allows this author to develop his unique short stories. The author's interest in the Middle Ages, however, did not imply any kind of glorification of a long-disappeared world. Instead, he draws from medieval concepts as he found them in literary sources and instrumentalized them for his own purposes to explore fundamental human issues - here pertaining to the question regarding good rulers and their moral and ethical obligations toward the people.

\section{7. "Der Strom"}

This is, finally, also evident in his fascinating tale, "Der Strom"(The River), which appeared first in his collection of novellas, Die Flamme im Säulenholz (1953; reprinted several times until 1965; The Flame in the Wooden Column here I quote from Bergengruen, Schnaps mit Sakuska 1987; Schnaps with Sakuska), in which a young man, Christian finds himself separated from the urban society, from his contemporaries, and caught in the stifling world of his poor country estate which he had inherited from his deceased father, a man who had dabbled in alchemy and other obscure sciences. He left behind also a number of manuscripts which Christian cannot read and yet does not want to sell. A highly independently minded young woman, Christiane, who has received an extraordinary education and who can read Latin, learns about this treasure and arrives one day to inspect those manuscripts. She realizes quickly that they represent extremely rare copies of famous alchemical and other necromantic texts, so she becomes absolutely intent, if not obsessed, with acquiring them.

Christian refuses, however, not because he wants to keep those manuscripts for himself, but because her interest means for him that she regularly returns to his estate to offer ever higher prices for those books. Eventually, when she has become completely irritated about his refusal and asks him straightforwardly what he would like to demand for those manuscripts, he suddenly reveals his real interest and demands the privilege of spending three nights with her. To his great surprise, she actually agrees, but she had already learned, as we find out later, in one of those manuscripts how to make a man fall asleep who wants to have sex with her. For two nights, he suffers from her magical skills and is deeply frustrated. Before the third night has arrived, he ambulates, rather worried about failing once again, along the shore of the river and arrives at a wooden sculpture of St. Christopher, the highly popular saint who had allegedly carried the Christ child across the river - a famous medieval religious legend best preserved in Jacobus de Voragine's mid-thirteenth-century Legenda aurea (Jacobus de Voragine 1993).

Here, at the sculpture, Christian encounters a Russian rafter woman (Struse) who provides him with a countermagic, which he only needs to place under the pillow, after having thrown away the mysterious object hidden underneath it. This breaks the power of the charm which had made him fall asleep, so now the sexual encounter can be accomplished to his full satisfaction. Although Christiane had tried to fight him off, simply having been scared of all men, she now accepts him as her husband, and the rest of the story then quickly develops with both experiencing a happy married life.

The entire narrative motif, with its structure of the three nights negotiated as a price for the manuscripts, finds many distant parallels in medieval and early modern literature, whether we think of Wolfdietrich B, Sigrdrífomál, 
Thüring von Ringoltingen's Melusine (there with the opposite conditions), or various predecessors of the fairy tales as collected by the Brothers Grimm ("Dornröschen"?), though Bergengruen developed it considerably further, adding innovative narrative angles of his own. The closest source, however, proves to be once again the Gesta Romanorum (Oesterley 1872/1980, no. 195, pp. 603-08), where the young man receives the decisive advice from a Roman philosopher about the charm hidden in the bed which makes him automatically fall asleep (Wesselski 1925, 163-168, which Bergengruen might well have consulted directly, instead of the Gesta Romanorum proper). In the Latin source, the philosopher (perhaps Virgil, as we learn from other versions) knows about this secretive chart since he himself had procured it, though we are not told how it then had gotten into the maid's possession.

In Bergengruen's version, we find out that Christiane had learned about this magical charm from the manuscripts in Christian's possession while she had leafed through them, so if he had known how to read a medieval Latin text, he would have understood her strategy right away. Those manuscripts obviously contained magical manuals, but only Christiane knew of their true value, which made her so obsessed that she was willing even to risk her virginity, though she trusted the magical charm that was to protect her. Finally, the entire configuration of this account pits two individuals 'against' each other who appear almost as predestined for one another, both being outsiders, separated from the rest of society by the metaphorical river which needs to be crossed for the events to proceed.

The Russian woman reappears only in the last moment of Christian's life and reveals to him that the reward which she had expected from him consisted only of his gratitude and happiness in life. Very similar to the crucial metaphor used by Gottfried von Straßburg in the prologue to his Tristan, this mysterious old woman reveals to him that the essence of all human existence would rest in black bread, spiced with nothing but salt, rich and nourishing. In Tristan, the reader is reminded of the fundamental insight that the story of true love is tantamount to eating bread, bitter and sorrowful, but hence leading to personal happiness. Whether Bergengruen drew directly from this metaphor, cannot be decided here, but the parallels are certainly striking. The author might have also thought about the symbolic significance of the river, or larger body of water (Tristan), which needs to be crossed for love to bloom and life to experience its full development to a maximum of its potentiality (Classen, Water in Medieval Literature 2018).

Most important for our approach pursued in this study, however, proves to be the intensive engagement with Saint Christopher, who was globally venerated since the fifth century throughout the entire Middle Ages and until the late twentieth century - he was eliminated from the official Catholic Church calendar only as late as in 1969 serving as the patron saint especially for travelers helping them to cross rivers without suffering from danger (Schneider 2005). Bergengruen, however, metamorphizes the legendary account and talks about the river which Christian cannot cross mentally, being separated from most of his contemporaries, caught in his own sense of incompetence and insecurity. Only once the Russian woman has provided him with the necessary magical means, can he finally overcome this character weakness, assert himself, and thus realize his deepest desires, which then quickly transforms him as a person, who can win Christiane's love and hand in marriage. Life then develops harmoniously and happily for him, as we can thus conclude, because St. Christopher had carried him across the river and allowed him thus to grow into a normal adult life.

Significantly, if Christian had not inherited those medieval manuscripts from his father, Christiane would have never shown any interest in him. Of course, she only granted those three nights with her to the young man because she believed to be safe from any consequences for herself. As a result of St. Christopher's involvement, however, at least via the Russian Strusen woman - 'Strusen' referring to the Russian rafters transporting wood to the Baltic Sea - the necromantic instrument to make the lover fall asleep was counteracted by some mysterious bag which she had given him, and this then forced Christiane to accept her lover as her future marriage partner. We would acknowledge today that this would constitute a form of rape, a very reprehensible sexual crime, though it is not fully reflected on in this narrative. Both the medieval and the modern version romanticize this relationship as happy and fulfilling for both, even though, through our modern lens, we also recognize and should condemn the degree of violence committed against the young woman. However, she had agreed to the condition set up by the young man, and this with the deliberate intention of deceiving him. Believing in her magical power, she was willing to gamble with the potential danger of prostitution, although this would still not justify Christoph's violent charge against her, taking her by force despite her pleading to spare her virginity.

At first sight, St. Christopher does not seem to play the crucial role we might have expected because the Strusen woman operates separately from him. However, Christian had met her while she had prayed in front of the sculpture, and he himself had poured all of his cash into her palm to pass it on as an offering to the saint, so we are on safe ground to assume that Bergengruen intended to predicate the entire story on Christopher's help in this situation. After all, the two lovers exchange their ideas about the true extent to which the saint had brought them together and give him full credit for this miraculous change of events and hearts. Both people are described before 
their marriage as blocked and isolated, shy of people, and incapable of reaching out to their social environment. Once they had crossed the river, both materially and metaphorically, their self-isolation was broken, and they found each other as a harmoniously matching couple. In order to explore the concepts of love, identity, and social involvement, Bergengruen specifically drew from the medieval belief in saints such as St. Christopher in order to come to terms with universal issues in human life. But he selected only one aspect of the medieval narrative, the love affair, and left out the second part in which the young man faces a deadly threat because he had pledged his life to a merchant in return for a loan to pay for the third night with the maid. The crucial issue is solved there when the maid, now the knight's beloved wife, cross-dresses, appears before court, and argues successfully that the merchant had only a right on the knight's flesh, but not on his blood - a theme which Shakespeare was later to pick up for his The Merchant of Venice (1596-1599, first printed in 1600; Drakakis, ed., 2010, pp. 60-61), but then he tinged the business transaction in strongly-anti-Semitic terms, which is not at all the case in the Gesta Romanorum, not to speak of Bergengruen's version.

It is worth mentioning here in passing that an anonymous fifteenth-century author of a Middle High German verse narrative, "Kaiser Lucius' Tochter" had also developed this motif, though the element of 'rape' is mostly removed, and there is still no indication of anti-Semitism. I would assume that Bergengruen was not familiar with this literary account despite the strong similarities and complex and meaningful aspects addressing love, sexuality, violence, magic, money lending, and the legal process. We would certainly need a detailed examination of "Kaiser Lucius' Tochter" as a significant contribution to fifteenth-century German literature. (Note 10) We recognize here, to be sure, a significant concatenation of medieval and modern literary texts all focused on more or less the same motif.

\section{Conclusion}

The analysis of these four novellas has demonstrated that Bergengruen offered creative, idiosyncratic approaches to the Middle Ages, utilizing a variety of themes and motifs that used to be popular in many different romances, treatises, and verse narratives. However, in clear contrast to many other modern authors dedicated to a form of playful medievalism, Bergengruen did not endeavor to imitate or paraphrase what his predecessors hundreds of years before him had already talked about. "The Naked Emperor" proves to be the closest to a specific source or group of source texts from the Middle Ages, but even there the author offers an entirely different approach, does not talk about the emperor's guilt as such, and identifies him instead as the one individual less guilty than everyone else and yet more noble and hence stronger than all of his subjects to take on the task of doing penance for the entire people.

In the other cases, Bergengruen also clearly proves to be influenced by medieval motifs, but he remodels them extensively and thus avoids the common trap of employing them for simple entertainment purposes. Instead, he rewrites medieval works for new intentions, redesigning them for ethical, moral, religious, and philosophical issues of relevance for the twentieth century and us today. In short, despite the historical framework, and despite the obvious familiarity with medieval literature at large, Bergengruen can be identified as a significant contributor to medievalism, but here understood as a medium to formulate concepts about social and spiritual issues fundamental in all of human life and inspired by medieval art and literature. Examining his short prose narratives, we can discover numerous direct connections with medieval literature.

Most impressively, his entire collection of short stories published under the title Der Tod von Reval (1939; Death from Reval [today Tallinn]), though hardly addressing the Middle Ages as such in concrete terms, proves to be generally predicated on the famous painting of the "Dance of Death" by Bernt Notke in St. Nicholas, Tallinn, from ca. 1465-1470 (see the prologue and the first story, "Report about the Course of Life and the Course of Death of a Curious Man, Bergengruen, Der Tod von Reval 1939; 1956). As we are told throughout the entire volume, closely following late medieval teachings, life and death are intimately interlaced with each other, and the living should not be worried about the dead since all belong to the same global continuum of all existence.

Bergengruen directly responded to numerous messages from medieval history, literature, philosophy, religion, and the arts in composing his novels and short stories. But he did not limit himself to engaging with them in a narrow fashion; instead, he drew, above all, deep inspirations from the medieval teachings for a discussion of timeless values and ideals. Little wonder that the revolutionary generations of the 1960s and 1970s lost their interest in this traditionalist author, but the relevance of his observations, themes, and motifs has not faded away. In fact, both medievalists and modernists can productively resort to Bergengruen's writing, certainly valuable contributions to twentieth-century German literature although they are often informed by medieval material at large.

In Bergengruen's œuvre we can grasp a significant voice from the twentieth century which had not lost the connection to the pre-modern past and established intriguing narrative and idealistic bridges between that world and the twentieth century. All four novellas discussed here invite the readers not only to think about wider human 
concerns, shortcomings, conflicts, and ideals, but also to revisit medieval literature as a significant treasure trove of romances, heroic epics, verse narratives, and courtly love poetry (Sobota 1962,193-94). There is more to Bergengruen's works than the experience of the unio mystica or of the merging of macrocosm and microcosm (Bänziger, 46). He commonly addresses human guilt, repentance, and the intervention of the divine, that is, the subject's effort to find its own individuality, character, and inner nature. Such notions are not really medieval, and mirror rather the modern person.

Nevertheless, we can definitely conclude with the observation that Bergengruen was deeply inspired by medieval ideals, but transformed them considerably for his own purposes, addressing his twentieth-century audience, caught in an existential crisis and hungry for a constructive redress, which these novellas and many other works by this writer offered in a welcome fashion. There is always a sense of consolation and hope, whereas the social, political, and economic criticism we are now wont to read about appears to be a bit removed. But what would be wrong with soul-searching, the quest for individual happiness, and the identification of one's own meaning and identity in an alienated world. The turn back to the Middle Ages and the early modern period as a source of inspiration served Bergengruen exceedingly well, who did not aim for any kind of escapism, but implemented a different, a more historical lens for his literary investigations of human ethics, morality, spirituality, and ideals.

\section{References}

Aberth, J. (2003). Knight at the Movies: Medieval History on Film. New York and London: Routledge.

Albrecht, C. ed. (2020). Imagination and Fantasy in the Middle Ages and Early Modern Times: Projections, Dreams, Monsters, and Illusions. Fundamentals of Medieval and Early Modern Culture, 24. Berlin and Boston: Walter de Gruyter.

Anderson, Mark M. (2001). German Intellectuals, Jewish Victims: a Politically Correct Solidarity," Chronicle of Higher Education, 48(8), pB7, 4p. Retrieved October 19, 2001 from https://www.chronicle.com/article/german-intellectuals-jewish-victims-a-politically-correct-solidarity/

Bänziger, H. (1983). Werner Bergengruen. Weg und Werk. 4th rev. ed. Bern: Francke.

Bartlett, R. (1986). Trial by Fire and Water: The Medieval Judicial Ordeal. Oxford: Clarendon Press.

Bergengruen, W. (1946). Die Feuerprobe: Novelle (1951). Stuttgart: Philipp Reclam jun., 1998. Print.

Bergengruen, W. (1947). Die drei Falken. Novelle. Dresden: Heyne, 1937; parallel to it, it also appeared in Celle: F. Schneekluth, 1937; here I draw from the edition published in Zürich by Die Arche.

Bergengruen, W. (1952). Der letzte Rittmeister. Munich: Nymphenburger Verlagshandlung.

Bergengruen, W. (1954). Die letzte Rittmeisterin: Wenn man so will ein Roman. Munich: Nymphenburger Verlagshandlung.

Bergengruen, W. (1956). Der Tod von Reval: Kuriose Geschichten aus einer alten Stadt (1939). Frankfurt a. M. and Hamburg: Fischer Bücherei.

Bergengruen, W. (1987). Schnaps mit Sakuska: Baltisches Lesebuch, ed. N. Luise Hackelsberger. 2nd ed. (1986). Zürich: Arche.

Bergengruen, W. (1996). Das Buch Rodenstein: Novellen. Frankfurt a. M. and Leipzig: Insel.

Bergengruen, Werner. Die Sultansrose und andere Erzählungen. Sammlung Klosterberg. Klosterberg and Basel: Verlag Benno Schwabe.

Bildhauer, B., Chris J. ed. (2017). The Middle Ages in the Modern World: Twenty-First Century Perspectives. Proceedings of the British Academy, 208. Oxford: Oxford University Press. https://doi.org/10.5871/bacad/9780197266144.001.0001

Burckhardt, C. J. (1968). Über Werner Bergengruen, mit vollständiger Bibliographie, fünf Porträtskizzen und Lebenslauf. Zürich: Verlag der Arche.

Celia, C., Simon, D., Felice, L., \& Amy, G. R. ed. (2012). Why the Middle Ages Matter: Medieval Light on Modern Injustice, London and New York: Routledge.

Chris, J., Conor, K., \& Klaus, O. ed. (2020). Making the Medieval Relevant: How Medieval Studies Contribute to Improving Our Understanding of the Present. Das Mittelalter: Perspektiven mediävistischer Forschung, 6. Berlin and Boston: Walther de Gruyter.

Classen, A. (1996). Hermann Hesse als Mediävist? Ein Essay. Michigan Germanic Studies, 19(2), 113-26. 
Classen, A. (1996). Seinskonstitution im Leseakt: Adolf Muschgs Der Rote Ritter als Antwort auf eine mittelalterliche These. Etudes Germaniques, 51(2), 307-27.

Classen, A. (2003). Der Kampf um das Mittelalter im Werk Thomas Manns: Der Zauberberg: Die menschliche Misere im Kreuzfeuer geistesgeschichtlicher Strömungen. Studia Neophilologica, 75(2003), 32-46. https://doi.org/10.1080/00393270310003865

Classen, A. (2007). The Medieval Chastity Belt: A Myth-Making Process. The New Middle Ages. Houndmills, Basingstoke, Hampshire, England, and New York: Palgrave Macmillan. https://doi.org/10.1057/9780230603097

Classen, A. (2018). Water in Medieval Literature: An Ecocritical Reading. Ecocritical Theory and Practice. Lanham, MD, Boulder, CO, et al.: Lexington Books.

Classen, A. (2021). From the Gesta Romanorum to Werner Bergengruen: Literary Mirrors for Princes from the Late Middle Ages to the Twentieth Century. Amsterdamer Beiträge zur älteren Germanistik, 81(2021), 1-27. https://doi.org/10.1163/18756719-12340218

Classen, A. (2021). Short Stories by Werner Bergengruen: A Selection of His Novellas. Newcastle upon Tyne: Cambridge Scholars Publishing.

Classen, A. (2021). Werner Bergengruen. Literary Encyclopedia. Retrieved January 25, 2021 from https://www.litencyc.com/php/speople.php?rec=true\&UID $=14708$

Dinzelbacher, P. (2020). Das fremde Mittelalter: Gottesurteil und Tierprozess. 2nd expanded ed. Schriftenreihe des Mittelalterlichen Kriminalmuseums Rothenburg ob der Tauber, 11. Darmstadt: wbg Academic.

Drakakis, J., \& William, S. (2010). The Merchant of Venice. The Arden Shakespeare, Third Series. London: Bloomsbury.

Dummschat, G. (2016). Klaus Störtebeker und die Hanse - Seefahrt und Piratenleben. Rostock: Hinstorff Verlag.

Elliott, A. B. R. (2021). Medievalism, Politics and Mass Media: Appropriating the Middle Ages in the TwentyFirst Century. Medievalism, 10. Woodbridge: D. S. Brewer.

Ermes-Körber, A. G. (1995). Zwei Künste, beflügelt von einem Ideal: eine Untersuchung des Falkenmotivs in der Lyrik, Epik und Minneallegorie des 12-14. Jahrhunderts. Amsterdam: Universität.

Fischer, H. ed. (1966). Die deutsche Märendichtung des 15. Jahrhunderts. Münchener Texte und Untersuchungen zur deutschen Literatur des Mittelalters, 12. Munich: C. H. Beck.

Frankfurt, A. M., Bern, et al. (2013). Erhebungen, Analysen und Vorschläge zur Weiterentwicklung der Mittelalterdidaktik im muttersprachlichen Deutschunterricht. Mediävistik zwischen Forschung, Lehr und Öffentlichkeit, 7: Peter Lang.

Gottfried, von S. (1980). Tristan. Ed. and trans. by Rüdiger Krohn. Stuttgart: Philipp Reclam jun.

Grosse, S., \& Ursula, R. (1989). Die Rezeption mittelalterlicher deutscher Dichtung: Eine Bibliographie ihrer Übersetzungen und Bearbeitungen seit der Mitte des 18. Jahrhunderts. Tübingen: Max Niemeyer.

Harty, K. J. (1999). The Reel Middle Ages: American, Western and Eastern European, Middle Eastern and Asian Films About Medieval Europe. Jefferson, NC, and London: McFarland.

Helen, Y. ed. (2015). The Middle Ages in Popular Culture: Medievalism and Genre. Cambria Studies in Classicism, Orientalism, and Medievalism. Amherst, NY: Cambria Press.

Heyse, P., \& Hermann, K. ed. (1871). Deutscher Novellenschatz. Vol. 1. Munich: Rudolph Oldenbourg, München.

International Medievalism and Popular Culture, ed. Louise D'Arcens and Andrew Lynch. New York: Cambria Press, 2014. Print.

Joachim, H., Frankfurt, A. M., \& Leipzig, ed. (1994). Modernes Mittelalter: Neue Bilder einer populären Epoche, Insel Verlag.

Jürgen, K. et al. ed. (1988). Mittelalter-Rezeption III: Gesammelte Vorträge des 3. Salzburger Symposions: 'Mittelalter, Massenmedien, Neue Mythen, Göppinger Arbeiten zur Germanistik, 479. Göppingen: Kümmerle.

Klapper, J. (2015). Nonconformist Writing in Nazi Germany: The Literature of Inner Emigration. Studies in German Literature, Linguistics, and Culture. Rochester, NY: Camden House. https://doi.org/10.1017/9781782045625

Kroll, Frank-Lothar, \& Rüdiger, von V. (2012). Schriftsteller und Widerstand: Facetten und Probleme der "Inneren 
Emigration”. Göttingen: Wallstein Verlag.

Kroll, Frank-Lothar, Hackelsberger, N. L., \& Sylvia, T. (2005). Werner Bergengruen - Schriftstellerexistenz in der Diktatur. Aufzeichnungen und Reflexionen zu Politik, Aufzeichnungen und Reflexionen zu Politik, Geschichte und Kultur 1940 bis 1963. Biographische Quellen zur Zeitgeschichte, 22. Munich: Oldenbourg. https://doi.org/10.1524/9783486707823

Leslie J. Workman, Kathleen Verduin. ed. (1996). Medievalism in Europe II. Studies in Medievalism VIII. Cambridge: D. S. Brewer.

Makoschey, K. (1998). Quellenkritische Untersuchungen zum Spätwerk Thomas Manns. "Joseph, der Ernährer", "Das Gesetz", "Der Erwählte". Thomas Mann Studien, 1. Frankfurt a. M.: Klostermann. https://doi.org/10.3196/9783465029373

Meriem, P., Karolyn, K. ed. (2015). The Middle Ages on Television: Critical Essays. Jefferson, NC: McFarland.

Miedema, N. R. (2018). “What's in a dream': Kriemhilds Falkentraum in den Niederlanden und Flandern,” Zwischen Sprachen en culturen: Wechselbeziehungen im niederländischen, deutschen und afrikaansen Sprachgebiet, ed. Ute K. Boone. Münster and New York: Waxmann, 216-224.

Müller, U. (2010). "Medievalism," Handbook of Medieval Studies: Terms - Methods - Trends, ed. Albrecht Classen. 3 vols. Berlin and New York: Walter de Gruyter, 1, 850-865. https://doi.org/10.1515/9783110215588.850

Neumann, S. (2010). Der gerichtliche Zweikampf: Gottesurteil - Wettstreit - Ehrensache. Mittelalter-Forschungen, 31. Ostfildern: Jan Thorbecke, 2010.

Pieroth, B. (2019). Recht und Literatur: von Friedrich Schiller bis Martin Walser. Munich: C. H. Beck, 2015. Print.

Prendergast, Thomas A. and Stephanie Trigg. Affective Medievalism: Love, Abjection and Discontent. Manchester: Manchester UP.

Rohmann, G. (2017). Jenseits von Piraterie und Kaperfahrt. Für einen Paradigmenwechsel in der Geschichte der Gewalt im maritimen Spätmittelalter. Historische Zeitschrift, 304.1, 1-48. https://doi.org/10.1515/hzhz-20170001

Schneider, M. (2005). Die Christophorus-Legende in Ost und West: Das Leben aus dem Glauben und seine bildhafte Darstellung in der frühchristlichen und abendländischen Tradition. Cologne: Koinonia-Oriens, 2005. Print.

Schwinghammer, Y. (2016). Das Mittelalter als Faszinosum oder Marginalie? Länderübergreifende.

Simone, C. M., \& Carole, M. C. ed. (2013). The Medieval Presence in the Modernist Aesthetic: Unattended Moments, Leiden and Boston: Brill.

Smets, A. (2009). "The Falconry Treatise by Artclouche de Alagona." Tiere und Fabelwesen im Mittelalter, ed. Sabine Obermaier. Berlin and New York: Walter de Gruyter, 55-77.

Sobot, E. (1962). Das Menschenbild bei Bergengruen: Einführung in das Werk des Dichters. Munich: Nymphenburger Verlagshandlung.

Spencer-Hall, A. (2018). Medieval Saints and Modern Screens: Divine Visions as Cinematic Experience. Knowledge Communities, 3. Amsterdam: Amsterdam UP. https://doi.org/10.5040/9789048551293

Tomasek, Tomas. (1985). Die Utopie im “Tristan” Gotfrids von Straßburg. Hermaea / Neue Folge, 49. Tübingen: Max Niemeyer. https://doi.org/10.1515/9783111350103

Walpuski, F. H. (2006). Aspekte des Phantastischen: Das Übernatürliche im Werk Werner Bergengruens. Frankfurt a. M.: Peter Lang.

Walz, D. (1994). Das Falkenbuch Friedrichs II. Graz: Akademische Druck- und Verlagsanstalt.

Weiss, G. H. (1987). “Werner Bergengruen,” German Fiction Writers, 1914-1945, ed. James Hardin. Dictionary of Literary Biography, 56. Detroit, MI: Thomson Gale, 27-38.

Wesselski, A. (1925). Märchen des Mittelalters. Berlin: Herbert Stubenrauch.

Wolf, J. (2004). Die Moderne erfindet sich ihr Mittelalter - oder wie aus der "mittelalterlichen Erdkugel" eine "neuzeitliche Erdscheibe" wurde. Colloquia academica / Akademie der Wissenschaften und der Literatur, Mainz: G, Geisteswissenschaften, 2004.5. Mainz: Akademie der Wissenschaften und Literatur.

Wollenberg, D. (2018). Medieval Imagery in Today's Politics. Past Imperfect. Leeds: Arc Humanities Press. 
https://doi.org/10.5040/9781641899079.ch-003

Woods, W. F. (2014). The Medieval Filmscape: Reflections of Fear and Desire in a Cinematic Mirror. Jefferson, NC: McFarland.

Ziegler, V. L. (2004). Trial by Fire and Battle in Medieval German Literature. Rochester, NY: Camden House.

Zink, M. (1998). The Enchantment of the Middle Ages, trans. by Jane Marie Todd. Parallax: Re-Visions of Culture and Society. Baltimore, MD, and London: The Johns Hopkins UP.

\section{Notes}

Note 1. Maybe people have always been in great need for imagination and fantasy since ordinary life is too pedestrian and banal. See the contributions to the recent volume Imagination and Fantasy in the Middle Ages and Early Modern Times (2020). Today, however, the Middle Ages often mean nothing but simply big business, with amusement parks, festivals, stores, book publishers, and many movie makers bank on the overarching intrigue exerted by that past world. See the contributions to International Medievalism and Popular Culture 2014; see also The Middle Ages on Television 2015; The Medieval Presence in the Modernist Aesthetic 2017; Prendergast and Trigg 2019. The research literature on this topic is legion by now.

Note 2. https://www.alternet.org/2021/03/fbi/; for the full letter,

see https://www.whitehouse.senate.gov/news/release/whitehouse-releases-letter-to-garland-on-oversight-mattersolc-politicization- (both last accessed on March 16, 2021). See now Wollenberg 2018.

Note 3. For the ideological and myopic perspective practiced in German academic discourse today, particular rly regarding the pre-eminence of all matters Jewish, see Anderson 2002. He does not address Bergengruen, but his central point underscores dramatically why the new generation after 1968 radically dismissed this writer as no longer politically correct, which in itself was a strongly ideological position.

Note 4. http://werner-bergengruen-gesellschaft.de/ (last accessed on March 16, 2021).

Note 5. Burckhardt 1968; Bänziger 1983; Kroll, Hackelsberger, and Taschka 2005; Walpuski 2006; Kroll and von Voss 2012; Klapper 2015; Weiss 1987; Pieroth 2015, ch. 4, 99-112; Classen 2021. For a selection of his shorter texts, especially his autobiographical notes, see Bergengruen, Schnaps mit Sakuska 1987. I published an English translation of his Der Tod von Reval, five other novellas, and one poem with Cambridge Scholars Publishing, 2021.

Note 6. See, for instance, Modernes Mittelalter 1994; Mittelalter-Rezeption III 1988); Zink 1998; Schwinghammer 2013. The literature on this topic is legion by now. A most useful reference work, however, also from a medieval perspective, proves to be Grosse and Rautenberg 1989. Bergengruen, however, is not even listed here.

Note 7. Bergengruen scholars have duly noted some of those medieval sources but have not pursued this topic in any particular way; see, for instance, Bänziger 1983, 47.

Note 8. The deep impact of the Middle Ages on the modern world, even the twenty-first century, has already been observed by a number of scholars; see, for instance, the contributions to Why the Middle Ages Matter 2012; and Making the Medieval Relevant 2020. For the political implications, often leading to mass murder, see, for instance, Bildhauer and Jones, ed., 2017; and Elliott 2021.

Note 9. Bergengruen, Die drei Falken 1937; parallel to it, it also appeared in Celle: F. Schneekluth, 1937; here I draw from the edition published in Zürich by Die Arche, 1947. Although extremely popular throughout the following decades, and even translated into numerous languages, modern scholarship has hardly ever engaged with it since the 1970s.

Note 10. Hanns Fischer, ed., no. 8, 71-88. The manuscript which used to contain this text is lost today, but the narrative was preserved through modern copies. See Fischer, 530-531.

\section{Copyrights}

Copyright for this article is retained by the author(s), with first publication rights granted to the journal.

This is an open-access article distributed under the terms and conditions of the Creative Commons Attribution license (http://creativecommons.org/licenses/by/4.0/). 